\title{
Analisis Kemampuan Komunikasi Matematis Siswa melalui Pembelajaran Kooperatif Tipe Jigsaw
}

\author{
Kuswandi ${ }^{1}$, Heni Pujiastuti ${ }^{2}$ \\ 1,2 Mathematics Education Departement, Universitas Sultan Ageng Tirtayasa \\ e-mail: henipujiastuti@untirta.ac.id
}

\begin{abstract}
ABSTRAK. Penelitian ini bertujuan untuk mendeskripsikan kemampuan komunikasi matematis siswa dengan menggunakan pembelajaran kooperatif tipe Jigsaw. Penelitian ini menggunakan desain diskriptif kualitatif dengan menggunakan model Miles and Huberman yang meliputi reduksi data, penyajian data, dan kesimpulan. Teknik pengambilan sampel menggunakan teknik purposive sampling. Teknik pengumpulan data pada penelitian ini menggunakan teknik tes dengan instrument soal posttest. Dengan menganalisis hasil posttest sampel penelitian dari masing-masing katagori, maka dapat ditemukan terdapat perbedaan kemampuan komunikasi matematis dari subjek penelitian yang dikelompokkan menjadi tiga yaitu kemampuan matematika tinggi, sedang dan rendah. Pembelajaran matematika melalui model pembelajaran kooperatif tipe Jigsaw berpengaruh pada peningkatan kemampuan komunikasi matematis siswa.
\end{abstract}

Keywords : komunikasi matematis, pembelajaran kooperatif, jigsaw.

\section{PENDAHULUAN}

Sampai saat ini peran guru dalam membangun kemampuan komunikasi matematis siswa khususnya dalam pembelajaran matematika masih sangat terbatas. Kemampuan komunikasi merupakan aspek yang sangat penting yang perlu dimiliki oleh siswa yang ingin berhasil dalam studinya. Kemampuan komunikasi yang efektif merupakan kemampuan yang perlu dimiliki oleh siswa untuk semua mata pelajaran. Matematika sebagai wahana pendidikan, tidak hanya dapat digunakan untuk mencapai satu tujuan seperti untuk mendidik siswa tetapi juga dapat membentuk kepribadian siswa dan mengembangkan keterampilan tertentu.

Matematika adalah ilmu abstrak dan deduktif, matematika adalah pengetahuan yang mempelajari pola, bentuk, dan struktur dan matematika adalah aktivitas manusia (Umar, 2012). Menurut (Depdiknas, 2006) tujuan pembelajaran matematika adalah: (1) memahami konsep matematika, mnjelaskan keterkaitan antar konsep dan mengaplikasikan konsep atau algoritma, secara luwes, akurat, efisien dan tepat dalam pemecahan masalah; (2) menggunakan penalaran pada pola dan sifat, melakukan manipulasi matematika dalam membuat generalisasi, menyusun bukti, atau menjelaskan gagasan dan pernyataan matematika; (3) memecahkan masalah yang meliputi kemampuan memahami masalah, merancang model matematika, menyelesaikan model dan menafsirkan solusi yang diperoleh; (4) mengkomunikasikan gagasan dengan simbol, tabel, diagram atau media lain untuk memperjelas keadaan dan masalah; (5) memiliki sikap menghargai matematika dalam kehidupan, yaitu memiliki rasa ingin tahu, perhatian, dan minat dalam mempelajari matematika serta sikap ulet dan percaya diri dalam pemecahan masalah (Sari, 2017). Jadi, sebagaimana dikatakan oleh Permendiknas No.22 bahwa salah satu tujuan pembelajaran matematika adalah mengkomunikasikan gagasan dengan simbol, tabel, diagram atau media lain untuk memperjelas situasi dan masalah. Istarani (2012) menyatakan bahwa "to improve students' mathematical communication ability need to motivated them to give relevant reason on their answer"s, untuk 
meningkatkan kemampuan komunikasi matematis siswa, perlu untuk memotivasi mereka untuk memberikan alasan yang relevan pada jawaban mereka. Hal ini bertujuan agar siswa dapat memahami konsep matematika yang dipelajari secara bermakna. Ini jelas menunjukkan bahwa kemampuan komunikasi matematis diperlukan.

Secara umum, komunikasi dapat diartikan sebagai proses untuk mencapai tujuan komunikasi itu sendiri yaitu untuk menyampaikan pesan dari satu orang ke orang lain baik secara langsung (lisan) maupun tidak langsung. Proses komunikasi juga membantu membangun makna dan kelanggengan untuk ide-ide dan membuatnya menjadi publik. Proses belajar dan mengajar juga berkontribusi untuk mengembangkan kemampuan komunikasi siswa, dengan menyampaikan ide dan pendapat mereka guru, dapat mengetahui seberapa banyak siswa belajar dan memahami materi. Siswa ditantang untuk berpikir dan memberikan alasan tentang matematika juga mengkomunikasikan hasil pikiran mereka kepada orang lain secara lisan atau tertulis, mereka belajar untuk menjadi jelas dan meyakinkan dan ini adalah proses komunikasi.

Komunikasi dalam matematika disebut kemampuan komunikasi matematis adalah kemampuan menyampaikan sesuatu yang dikenal melalui pidato atau dialog tulisan tentang konsep, rumus, atau strategi pemecahan masalah dalam matematika (Sari, 2017). Kemampuan komunikasi matematis mencerminkan pemahaman siswa. Konsep atau informasi matematika yang diberikan oleh seorang guru kepada siswa, atau siswa mendapatkannya dengan sendirinya yaitu ketika transformasi informasi matematika dari komunikator ke komunikan terjadi. Dalam matematika, kualitas penafsiran dan respons sering menjadi masalah khusus. Ini adalah hasil dari karakteristik matematika itu sendiri yang syarat dengan istilah dan simbol. Oleh karena itu, kemampuan komunikasi matematis menjadi kebutuhan khusus dalam belajar matematika.

Uraian di atas menunjukkan pentingnya kemampuan komunikasi matematis dalam belajar matematika, dan memiliki peran penting dalam membangun pengetahuan matematika dan mengekspresikan ide-ide matematika dari berbagai perspektif siswa. Melalui komunikasi, siswa dapat mengirimkan ide mereka kepada guru dan siswa lainnya. Hal ini sejalan dengan hasil penelitian yang dilakukan oleh Kusaeri (2018) yang menunjukkan bahwa terdapat perbedaan kemampuan komunikasi matematis pada siswa, bagi siswa yang berkemampuan matematika tinggi mengalami lupa atau forgotten lost terhadap suatu konsep tertentu siswa yang berkemampuan matematika rendah sering mengalami kesalahan dan lupa dikarenakan konsep-konsep yang dibutuhkan di short term memory tidak tersimpan dengan baik oleh long term memory.

Berdasarkan observasi awal di kelas XII pada SMK Pandeglang Banten diperoleh bahwa pelajaran masih berpusat pada guru, bukan pada siswa. Hasil dalam pembelajaran semacam ini membuat siswa pasif dalam mengembangkan pikiran mereka atau menyampaikan ide mereka. Dari pengamatan dan tes pendahuluan ini juga ditemukan bahwa kemampuan komunikasi matematis siswa tergolong masih kategori rendah yaitu dibawah angka 60. Rendahnya kemampuan komunikasi matematis siswa terhadap materi pembelajaran menjadikan siswa menganggap matematika merupakan pelajaran yang sulit (Asmara \& Afriansyah, 2018).

Selain itu, siswa juga masih kesulitan dalam membuat suatu kesimpulan dengan menggunakan bahasa sendiri. Padahal salah satu bentuk kemampuan komunikasi matematis dalam menyelesaikan masalah, sebagaimana yang dinyatakan oleh Ansari (Sari, 2017) adalah menjelaskan situasi masalah dengan kata-kata sendiri dan melakukan perhitungan. Dari beberapa soal postest, terdapat jawaban dari beberapa soal yang mereka tuliskan belum mendekati jawaban yang benar, itu berarti kemampuan siswa dalam menjelaskan masalah dengan kata-kata sendiri dan melakukan perhitungan juga lemah.

Setelah melihat hasil tes tersebut, maka dilakukanlah kegiatan wawancara untuk memperoleh data yang lebih mendalam. Wawancara dilakukan dengan guru matematika kelas XII. Hasil wawancara menunjukkan bahwa level kemampuan komunikasi matematis siswa di 
kelas XII belum berkembang secara optimal. Sebagian besar siswa mengalami kesulitan dalam menulis, menjelaskan, dan menyajikan ide matematika. Siswa kurang dalam berinteraksi untuk membangun komunikasi dengan guru dan lainnya siswa. Wawancara juga dilakukan dengan beberapa siswa, menemukan bahwa beberapa siswa tidak tertarik untuk belajar matematika, mereka menganggap belajar matematika itu sulit dan semuanya materi tentang matematika sulit dipahami. Selain itu, mereka menginginkan pembelajaran Prosesnya lebih bervariasi, beberapa dari mereka ingin berbagi dalam belajar, siswa yang memiliki kemampuan tinggi ingin membantu siswa lain.

Kurangnya kemampuan komunikasi matematika dapat menyebabkan kesalahpahaman dalam memahami konsep matematika atau menimbulkan masalah yang lebih kompleks, yang pada akhirnya siswa tidak dapat memecahkan masalah. Oleh karena itu, diperlukan suatu upaya untuk menemukan pendekatan yang tepat yang akan membantu siswa mengembangkan kemampuan komunikasi matematis mereka dan mendorong mereka untuk mencapai tujuan pembelajaran. Guru harus hati-hati dalam penggunaan model pembelajaran harus menyesuaikan dengan materi pembelajaran agar pemahaman konsep matematika tidak salah dan sesuai dengan tujuan pembelajaran (Budi Mulyono, 2018).

Cara belajar yang baik adalah belajar yang memberi siswa kesempatan penuh untuk mengekspresikan pendapat dan ide mereka serta pendekatan yang lebih efektif, kreatif, dan menyenangkan. Atas dasar ini, penulis mencoba menerapkan pembelajaran kooperatif tipe Jigsaw untuk melihat peningkatan kemampuan komunikasi matematis siswa. Pembelajaran kooperatif tipe Jigsaw memiliki tujuan untuk memperluas pengetahuan dan akurasi siswa dalam memahami konsep. Menurut (Istarani 2012), model pembelajaran Jigsaw mendorong siswa untuk berani mengekspresikan pendapat mereka.

Hal ini dapat terjadi ketika guru memberikan penjelasan tentang materi kemudian siswa memiliki waktu untuk membaca dan menulis hal-hal yang mereka ketahui. Selanjutnya, siswa melaksanakan pembelajaran kooperatif tipe Jigsaw, dimana siswa dibagi menjadi 4-6 kelompok, kemudian kelompok tersebut disebut tim asal, lalu dari tim asal harus mengirimkan utusan 1 orang siswa untuk membentuk tim baru yang disebut tim ahli. Tim ahli akan diberi tugas menyelesaikan permasalahan yang diberikan oleh guru berupa lembar kerja peserta didik sesuai materi ajar yang akan di sampaikan hari itu. Setelah didiskusikan dan mendapatkan pemecahan permasalahan yang diberikan guru, semua anggota tim ahli kembali ke tim asal yaitu untuk menyampaikan dan memaparkan hasil diskusi dari tim ahli kepada anggota tim asal secara bergantian. Kemudian terjadi diskusi baru dalam tim asal untuk penyelesaian masalah yang diberikan guru. Setelah mufakat hasil diskusi tim asal, maka proses selanjutnya pemaparan hasil diskusi masing-masing kelompok ke depan kelas sampai semua permasalahan matematika yang diberikan oleh guru terselesaikan, dengan menarik kesimpulan diakhir pembelajaran.

Itulah mengapa peneliti mencoba menerapkan pembelajaran kooperatif tipe Jigsaw kepada siswa kelas XII SMK Pandeglang Banten adalah salah satu pendekatan pembelajaran yang di perkirakan memenuhi kebutuhan siswa untuk mengembangkan komunikasi matematis melalui pemahaman matematis yang dirangsang oleh penyelesaian masalah dalam bentuk lembar kerja untuk didiskusikan secara kelompok. Hal itu dikarenakan pendekatan pembelajaran tipe Jigsaw ini dapat memberikan kesempatan bagi siswa untuk memberikan pendapat mereka dalam sebuah diskusi kelompok. Adapun sintaks dari pendekatan pembelajaran matematika SMK Pandeglang Banten dalam penelitian ini dimodifikasi dari sintaksis pembelajaran tipe Jigsaw sebagaimana disampaikan oleh Aronson (2019) menyebutkan terdapat 6 fase dalam sintaks atau langkahlangkah pembelajaran kooperatif tipe Jigsaw: 
Fase 1: Membentuk kelompok asal yang heterogen. Guru membagi siswa dalam kelompok asal berjumlah 4-6 orang.

Fase 2: Membagikan tugas/materi. Guru membagi pelajaran yang akan dibahas ke dalam 4-6 bagian. Siswa membagi materi yang berbeda pada tiap siswa dalam tiap kelompok.

Fase 3: Membentuk kelompok ahli. Siswa dari masing-masing kelompok asal bergabung dengan siswa lain yang memiliki bagian materi pelajaran yang sama.

Fase 4: Diskusi kelompok ahli. Siswa berdiskusi dalam kelompok berdasarkan kesamaan materi masing-masing siswa.

Fase 5: Diskusi kelompok asal. Siswa kembali ke kelompok asalnya masing-masing dan bergiliran menyampaikan materi yang didapat dan telah didiskusikan di tim ahli kepada anggota kelompok yang lain.

Fase 6: Evaluasi. Guru melakukan penilaian untuk mengukur hasil belajar siswa secara individu mengenai seluruh pembahasan.

Berdasarkan sintaks, siswa diberi kesempatan untuk berdiskusi dengan teman-teman mereka dan kemudian perlu mengekspresikan ide, pendapat atau jawaban mereka terhadap masalah yang diberikan guru. Setelah itu bersama dengan guru pemebahasan materi dilanjutkan untuk mendapatkan sebuah rangkuman. Sintaksis yang dimiliki tipe Cooperative Learning Jigsaw, memberikan banyak peluang bagi siswa untuk mengembangkan kemampuan komunikasi matematis mereka dalam kelompok atau diri mereka. Dengan menggunakan konsep pembelajaran kooperatif tipe Jigsaw, membuat belajar matematika dengan cara yang lebih bermakna karena siswa mencoba memahami materi dengan secara mandiri bersama-sama rekan sekelompoknya dan kemudian berkomunikasi kembali dengan memberikan umpan balik.

Indikator yang digunakan untuk melihat kemampuan komunikasi matematis dalam penelitian ini adalah: (1) kemampuan menjelaskan masalah matematika ke dalam gambar atau grafik, (2) kemampuan menjelaskan situasi masalah dengan kata-kata sendiri, dan (3) kemampuan menyatakan masalah matematika ke dalam bentuk diagram dan melakukan perhitungan untuk menyelesaikannya (Ansari, 2012). Berdasarkan penjelasan di atas, masalah yang dibahas pada penelitian ini terkait dengan indikator analisis kemampuan komunikasi matematis siswa yang ditunjukkan selama penerapan pembelajaran kooperatif tipe Jigsaw dan juga untuk melihat apakah tipe Jigsaw dapat menjadi salah satu pendekatan pembelajaran yang dapat digunakan untuk meningkatkan kemampuan komunikasi matematis siswa.

Oleh karena itu, tujuan penelitian ini adalah untuk menganalisis kemampuan komunikasi matematis siswa di kelas XII pada salah satu SMK di Kabupaten Pandeglang Banten yang diupayakan muncul selama pelaksanaan pembelajaran kooperatif tipe Jigsaw dan menemukan bahwa pembelajaran kooperatif tipe Jigsaw dapat meningkatkan kemampuan komunikasi matematis siswa. Terdapat beberapa penelitian terdahulu yang pernah dilakukan dengan model pembelajaran kooperatif tipe Jigsaw. Diantaranya adalah penelitian Fahmi (2012) yang menyimpulkan bahwa pembelajaran dengan menggunakan model kooperatif tipe Jigsaw lebih baik dalam meningkatkan pemahaman matematis siswa daripada pembelajaran konvensional. Hasil penelitian Sugianto (2014) yang menyimpulkan bahwa pembelajaran dengan menggunakan model kooperatif tipe Jigsaw lebih baik dalam meningkatkan komunikasi matematis siswa dibandingkan dengan menggunakan tipe STAD. Dari penjelasan di atas, penulis ingin mengetahui apakah peningkatan kemampuan komunikasi matematis siswa yang mendapat pembelajaran melalui model kooperatif tipe Jigsaw lebih baik daripada kemampuan awal matematis siswa. 


\section{METODE}

Metode penelitian yang digunakan oleh peneliti adalah metode penelitian deskriptif dengan pendekatan kualitatif. Tujuan penelitian memberikan gambaran yang lebih mendalam mengenai kemampuan komunikasi matematis siswa melalui model pembelajaran kooperatif tipe Jigsaw. Sebagaimana yang dikemukakan oleh (Lexy, 2007) bahwa deskriptif kualitatif adalah penelitian yang dilakukan untuk memahami fenomena yang dialami oleh subjek penelitian yang terkait dengan perilaku, persepsi, tindakan, dll., secara holistik dan dengan cara mendeskripsikan katakata dan bahasa, dengan konteks ilmiah tertentu dan dengan memanfaatkan berbagai metode ilmiah.

Subjek penelitian ini adalah siswa kelas XII Kimia Industri di salah satu Sekolah Menengah Kejuruan di Pandeglang Banten yang berjumlah 22 orang siswa. Teknik pengumpulan data yang digunakan adalah teknik tes dengan intrumen penelitian berupa soal tes, yaitu posttest. Soal posttest ini memuat indikator kemampuan komunikasi matematika yang diberikan pada akhir penerapan pembelajaran kooperatif tipe Jigsaw yang terdiri dari 10 soal, untuk mengukur kemampuan komunikasi matematis siswa. Data primer dalam penelitian ini adalah hasil posttest siswa yang dibuat berdasarkan indikator kemampuan komunikasi matematis yang telah ditentukan sebelumnya. Hasil posttest dianalisis dengan menentukan kesesuaian jawaban siswa terhadap indikator kemampuan komunikasi matematis yang diharapkan. Dari data hasil posttest tersebut akan terlihat hasil rata-rata posttest siswa untuk dibandingkan dengan skor minimum matematika yang ditentukan oleh sekolah untuk melihat pembelajaran kooperatif tipe Jigsaw dalam meningkatkan kemampuan komunikasi matematis siswa. Kemudian data hasil post tes dikategorikan sebagai berikut :

Tabel 1. Kategori Hasil Kemampuan Matematis Siswa berdasarkan Hasil Posttest

\begin{tabular}{ccc}
\hline Katagori & Nilai & Keterangan \\
\hline A & $91-100$ & sangat baik \\
B & $81-90$ & baik sekali \\
C & $71-80$ & baik \\
D & $61-70$ & cukup baik \\
E & $<60$ & kurang \\
\hline
\end{tabular}

Untuk menentukan sampel penelitian dengan menggunakan purposive sampling. Teknik analisis data yang digunakan peneliti menggunakan teknik Miles dan Hubberman (Sugiyono, 2012), yang meliputi: reduksi data; penyajian data; dan penyimpulan data. Mereduksi berarti merangkum, memilih hal-hal pokok, dan memfokuskan pada masalah yang ingin dianalisis. Dengan reduksi data, maka gambaran kemampuan komunikasi matematis akan semakin jelas. Setelah data direduksi, kemudian data disajikan. Penyajian data dilakukan dalam bentuk uraian singkat, bagan, atau hubungan antar kategori. Dengan penyajian data, maka akan memudahkan memahami apa yang terjadi, dan dapat digunakan untuk merencanakan apa yang akan dilakukan selanjutnya. Langkah selanjutnya adalah penarikan kesimpulan (Gunawan, Subekti, Subekti, \& Khusna, 2018). Hasil kesimpulan berupa gambaran tentang kemampuan siswa komunikasi matematis siswa pada materi statistiska dengan menggunakan pembelajaran kooperatif model Jigsaw.

\section{HASIL DAN PEMBAHASAN}

Setelah selesai pemberian materi pembelajaran dalam satu Kompetensi Dasar, di akhir pembelajaran peneliti memberikan posttest kepada subjek penelitian. Dan berdasarkan hasil posttest siswa kelas XII Kimia Industri SMK Pandeglang Banten diperoleh data nilai sebagai berikut : 
Tabel 2. Data Hasil Posttest

\begin{tabular}{cccc}
\hline Siswa & Nilai & Kategori & Keterangan \\
\hline 1 & 88 & B & Baik sekali \\
2 & 88 & B & Baik sekali \\
3 & 84 & B & Baik sekali \\
4 & 84 & B & Baik sekali \\
5 & 80 & B & Baik sekali \\
6 & 84 & B & Baik sekali \\
7 & 88 & B & Baik sekali \\
8 & 88 & B & Baik sekali \\
9 & 80 & C & Baik \\
10 & 80 & C & Baik \\
11 & 80 & C & Baik \\
12 & 72 & C & Baik \\
13 & 72 & C & Baik \\
14 & 72 & C & Baik \\
15 & 76 & C & Baik \\
16 & 76 & C & Baik \\
17 & 76 & C & Baik \\
18 & 68 & D & Cukup baik \\
19 & 68 & D & Cukup baik \\
20 & 68 & D & Cukup baik \\
21 & 64 & D & Cukup baik \\
22 & 64 & D & Cukup baik \\
\hline
\end{tabular}

Hasil posttest menunjukkan bahwa nilai tertinggi adalah 88,00 dan nilai terendah 64,00 dengan rata-rata nilai 77,27. Yang tergolong kategori baik sekali sebanyak 8 orang siswa, yang tergolong kategori baik 9 orang dan yang tergolong cukup baik sebanyak 5 orang.

Dari hasil posttest 22 orang siswa dikategorikan mempunyai tingkat kemampuan komunikasi matematis berbeda meskipun perlakuan pembelajaran dilakukan dengan cara yang sama. Bagi siswa yang termasuk ke dalam kategori baik sekali, menunjukan bahwa tiga indikator kemampuan komunikasi matematis terpenuhi yaitu indikator 1, 2 dan 3, hanya sedikit kekurangan dalam penjelasan. Sedangkan siswa yang di kategorikan baik jika dua indikator kemampuan komunikasi matematis terpenuhi yaitu indikator 1 dan 2, 1 dan 3 atau 2 dan 3. Sedangkan dikategorikan cukup baik karena ada salah satu indikator kemampuan komunikasi matematis terpenuhi yaitu baik indikator 1, 2 atau 3 .

Tabel 3. Data Persentase Siswa Sesuai Indikator Kemampuan Komunikasi Matematis

\begin{tabular}{clccc}
\hline Nomor & \multicolumn{1}{c}{ Indikator } & Nomor Soal & Jumlah Siswa & \% \\
\hline 1 & $\begin{array}{l}\text { kemampuan menjelaskan masalah matematika } \\
\text { dari bentuk gambar atau diagram } \\
\text { kemampuan untuk menjelaskan situasi } \\
\text { masalah matematika dengan kata-katanya } \\
\text { sendiri } \\
\text { kemampuan menyatakan masalah matematika } \\
\text { secara tertulis ke dalam bentuk gambar atau } \\
\text { diagram }\end{array}$ & 7 & 22 & 100 \\
& 8 & 8 & 36,09 \\
\hline
\end{tabular}

Dari tabel 3 menunjukkan bahwa dari 22 siswa yang dapat menjawab soal nomor 6 dan sesuai indikator ke-1 sebanyak 22 siswa atau 100\%. Untuk soal nomor 7 yang sesuai indikator ke2 dapat diselesaikan oleh 13 orang atau 59,09\%. Sedangkan soal nomor 8 yang sesuai dengan indikator ke-3 dapat diselesaikan oleh 8 orang atau 36,36\%.

Dengan menggunakan teknik purposive sampling, maka peneliti mengambil sampel dari subjek penelitian sebanyak 3 orang responden untuk mewakili masing-masing kategori, yaitu kategori baik sekali, baik dan cukup baik. Dan berikut sampel lembar jawaban siswa dari 3 orang 
responden yang sesuai dengan indikator kemampuan komunikasi matematis siswa pada materi penelitian yaitu statistika adalah :

1. Responden 1 ( $\mathrm{S} 1$ )

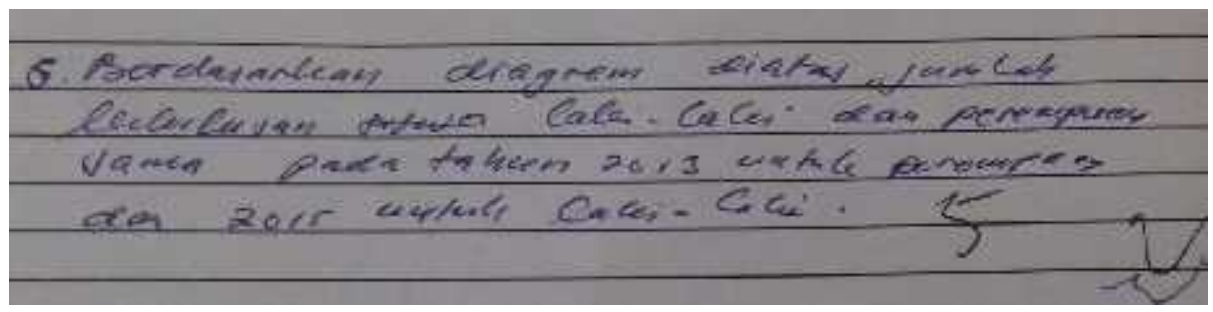

Gambar 1. Jawaban Responden 1 yang Sesuai dengan Indikator Ke-1

Dari gambar 1 menujukkan bahwa jawaban responden 1 dapat menyelesaikan pertanyaan no 6 yang berupa diagram garis tentang banyaknya alumni di suatu SMK X yang jumlah laki-laki dan perempuannya sama, ini berarti siswa tersebut dapat memahami dan bisa membaca permasalahan yang berbentuk gambar atau diagram sebagaimana sesuai dengan indikator kemampuan menjelaskan masalah matematika dari bentuk gambar atau diagram.

2. Responden 2 (S2)

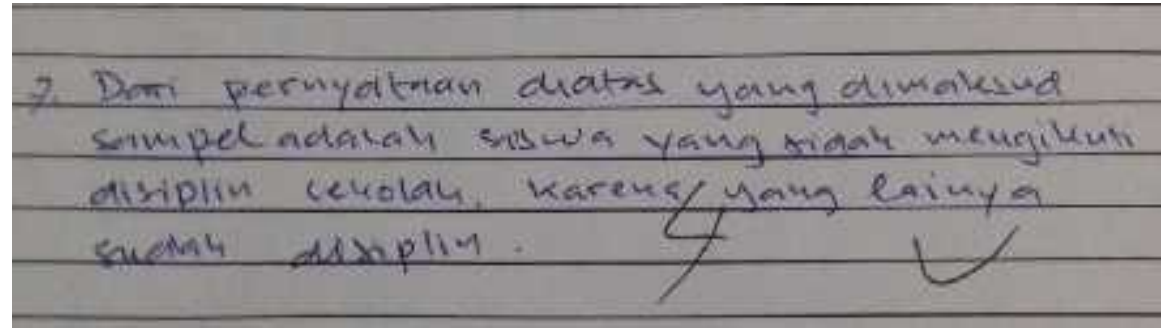

Gambar 2. Jawaban Responden 2 yang Sesuai dengan Indikator ke-2

Dari gambar 2 menujukkan bahwa jawaban responden 2 dapat menyelesaikan pertanyaan no 7 yang berupa pernyataan tentang disiplin siswa di suatu SMK X, ini berarti siswa tersebut dapat memahami permasalahan yang berupa pernyataan dan menjawab dengan bahasanya sendiri, meskipun masih kurang tepat dalam penjelasannya namun sudah sesuai dengan indikator kemampuan untuk menjelaskan situasi masalah matematika dengan kata-katanya sendiri.

3. Responden $3(\mathrm{~S} 3)$

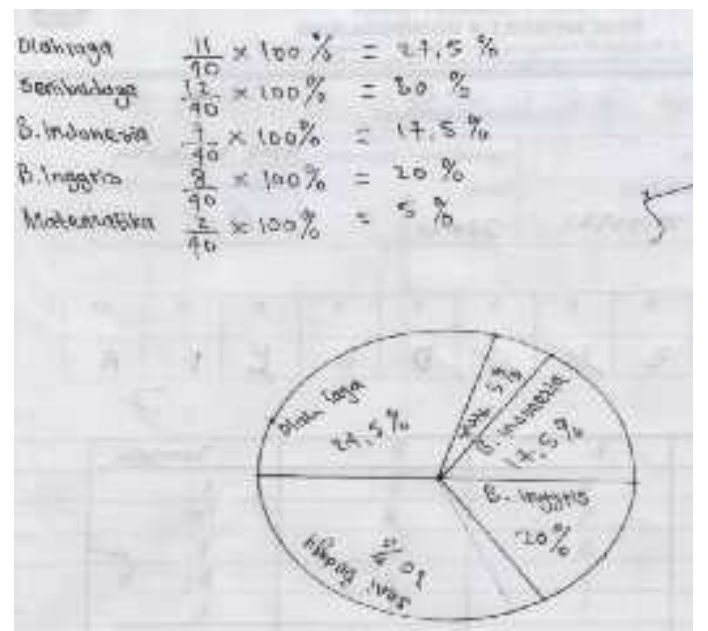

Gambar 3. Jawaban Responden 3 yang Sesuai dengan Indikator ke-3 
Dari gambar 3 menujukkan bahwa jawaban responden 3 dapat menyelesaikan pertanyaan no 8 yang berupa soal cerita tentang mata pelajaran favorit di suatu SMK X , ini berarti siswa tersebut dapat memahami permasalahan matematika dan diselesaikan dalam bentuk gambar atau diagram, sebagaimana sesuai dengan indikator kemampuan menyatakan masalah matematika secara tertulis ke dalam bentuk gambar atau diagram.

Adapun data yang diperoleh dari 3 responden yang mewakili dari sampel siswa subjek penelitian adalah sebagai berikut:

1) S1 adalah siswa yang memiliki kemampuan matematika sedang pada materi Statistika. Berdasarkan hasil tes tulis kemampuan komunikasi matematika, siswa ini termasuk dalam siswa yang memiliki kemampuan komunikasi matematika cukup baik. Skor yang diperoleh dari tes tulis ulangan harian adalah 64,00. Ada 3 indikator kemampuan komunikasi matematika yaitu kemampuan menjelaskan masalah matematika dalam bentuk gambar atau diagram, kemampuan menjelaskan situasi masalah dengan kata-kata sendiri, dan kemampuan menyatakan masalah matematika ke dalam bentuk diagram dan melakukan perhitungan untuk menyelesaikannya. Dari ketiga indikator kemampuan komunikasi matematika, siswa ini hanya mampu memenuhi satu indikator tersebut dengan cukup baik yaitu indikator ke-1.

2) S2 adalah siswa yang memiliki kemampuan matematika sedang pada materi Statistika. Berdasarkan hasil tes tulis kemampuan komunikasi matematika, siswa ini termasuk dalam siswa yang memiliki kemampuan komunikasi matematika baik. Skor yang diperoleh dari tes tulis ulangan harian adalah 76,00. Ada 3 indikator kemampuan komunikasi matematika yaitu kemampuan menjelaskan masalah matematika dalam bentuk gambar atau diagram, kemampuan menjelaskan situasi masalah dengan kata-kata sendiri, dan kemampuan menyatakan masalah matematika ke dalam bentuk diagram dan melakukan perhitungan untuk menyelesaikannya. Dari ketiga indikator kemampuan komunikasi matematika,siswa ini hanya mampu memenuhi dua indikator tersebut dengan baik yaitu indikator ke1 dan yang ke-2.

3) S3 adalah siswa yang memiliki kemampuan matematika tinggi pada materi Statistika. Berdasarkan hasil tes tulis kemampuan komunikasi matematika, siswa ini termasuk dalam siswa yang memiliki kemampuan komunikasi matematika kategori baik sekali. Skor yang diperoleh dari tes tulis ulangan harian adalah 88,00. Ada 3 indikator kemampuan komunikasi matematika yaitu kemampuan menjelaskan masalah matematika dalam bentuk gambar atau diagram, kemampuan menjelaskan situasi masalah dengan kata-kata sendiri, dan kemampuan menyatakan masalah matematika ke dalam bentuk diagram dan melakukan perhitungan untuk menyelesaikannya. Hanya uraian penjelasan yang masih perlu diperbaiki. Dari ketiga indikator kemampuan komunikasi matematika, siswa ini sudah mampu memenuhi ketiga indikator tersebut dengan baik sekali.

Hasil analisis data kemampuan komunikasi matematika adalah sebagai berikut: dari 3 sampel subjek penelitian didapatkan 1 siswa mampu memenuhi semua indikator yaitu kemampuan menjelaskan masalah matematika dalam bentuk gambar atau diagram, kemampuan menjelaskan situasi masalah dengan kata-kata sendiri, dan kemampuan menyatakan masalah matematika ke dalam bentuk diagram dan melakukan perhitungan untuk menyelesaikannya. 1 siswa mampu memenuhi dua indikator kemampuan komunikasi matematis yaitu kemampuan menjelaskan masalah matematika dalam bentuk gambar atau diagram, kemampuan menjelaskan situasi masalah dengan kata-kata sendiri. Sedangkan 1 siswa hanya mampu memenuhi satu indikator yaitu kemampuan menjelaskan masalah matematika dalam bentuk gambar atau diagram.

Siswa berkemampuan matematika tinggi termasuk ke dalam siswa yang memiliki kemampuan komunikasi matematika sangat baik artinya siswa tersebut sudah mampu memenuhi ketiga indikator, siswa berkemampuan matematika sedang termasuk ke dalam siswa yang memiliki 
kemampuan komunikasi matematika cukup baik artinya siswa tersebut mampu memenuhi dua indikator, sedangkan siswa berkemampuan matematika rendah termasuk ke dalam siswa yang memiliki kemampuan komunikasi matematika kurang artinya siswa tersebut hanya mampu memenuhi satu indikator saja.

Berdasarkan analisis yang telah dilakukan terdapat perbedaan antara siswa yang kemampuan matematika tinggi, sedang, serta rendah, dan perbedaan ini mengisyaratkan bahwa terdapat aspek kemampuan komunikasi matematika siswa secara tertulis berbentuk posttest yang memisahkan antar siswa dengan kemampuan matematika yang berbeda. Sehingga dapat disimpulkan bahwa semakin rendah tingkat kemampuan matematika siswa maka kemampuan komunikasi matematika siswa juga semakin berkurang.

Hasil penelitian ini kurang sempurna, karena rubrik penelitian dibuat sendiri oleh peneliti, mungkin pada penelitian yang selanjutnya agar disempurnakan. Hasil tersebut selaras dengan penelitian yang menyatakan bahwa terdapat hubungan signifikan antara kemampuan matematika dan kemampuan komunikasi matematika siswa sehingga semakin tinggi kemampuan matematika siswa maka kemampuan komunikasi matematikanya semakin tinggi pula (Damayanti, 2012). Hasil tersebut juga selaras dengan penelitian yang menyatakan bahwa penerapan metode accelerated learning berhasil meningkatkan kemampuan komunikasi matematis siswa (Permata, 2015).

\section{KESIMPULAN}

Dari hasil analisis data yang sesuai dengan indikator kemampuan komunikasi matematis, maka dapat disimpulkan: 1) Subjek penelitian dikatakan berkemampuan matematika tinggi apabila telah menguasai ketiga indikator kemampuan komunikasi matematis dengan baik sekali atau minimal n kategori B, yaitu sebanyak 8 orang. Subjek penelitian dikatakan berkemampuan matematika sedang apabila telah menguasai paling tidak satu indikator kemampuan komunikasi matematis dengan cukup baik yaitu pada kategori C sebanyak 9 orang dan kategori D sebanyak 5 orang. Dan subjek penelitian dikatakanberkemampuan matematika rendah apabila belum menguasai indikator kemampuan komunikasi matematis dengan baik yaitu dalam kategori E; 2) pembelajaran matematika melalui model pembelajaran kooperatif tipe Jigsaw berpengaruh pada peningkatan kemampuan komunikasi matematis siswa.

\section{REFERENSI}

Asmara, R., \& Afriansyah, E. A. (2018). Perbedaan Peningkatan Kemampuan Komunikasi Matematis Siswa antara Model Eliciting Activities dan Discovery Learning. Suska Journal of Mathematics Education, 4(2), 78-87.

Budi Mulyono, Hapizah. (2018). Pemahaman Konsep dalam Pembelajaran Matematika. Jurnal Kalamatika, 3(2), 103-122.

Damayanti, D. (2012). Penerapan Metode Accelerated Learning dalam Pembelajaran Matematika untuk Meningkatkan Kemampuan Komunikasi Matematis Siswa SMP. Tesis Universitas Pendidikan Indonesia (tidak diterbitkan).

Depdiknas. (2006). Permendiknas No 22 Tahun 2006 Tentang Standar Isi. Jakarta: Depdiknas.

Gunawan, G., Subekti, F. E., \& Subekti, F. E., (2018). Kemampuan Analogi Matematis Mahasiswa pada Mata Kuliah Kalkulus Differensial.Kalamatika Jurnal Pendidikan Matematika, 3(2), 223-238.

Istarani. (2012). 58 Model Pembelajaran Inovatif. Medan: Media Persada

Kusaeri. (2018). Proses Berpikir Siswa dalam Menyelesaikan Masalah Matematika Berdasarkan 
Teori Pemrosesan Informasi. Suska Journal of Mathematics Education, 4 (2), 125-141.

Lexy, J. M. (2007). Metodologi Penelitian Kualitatif Edisi Revisi. Bandung: PT Remaja Rosdakarya.

Permata, P., C., Kartono, \& Sunarmi. (2015). Analisis Kemampuan Komunikasi Matematis Siswa Kelas VIII SMP pada Model Pembelajaran TSTS dengan Pendekatan Scientific. Unnes Journal of Mathematics Education, 4(2), 127-133 .

Sari, D. M. (2017). Analysis Of Students' Mathematical Communication Ability By Using Cooperative Learning Talking Stick Type. Infinity Journal, 6(2), 183-194.

Sugiyono. (2012). Metode Penelitian Kuantitatif, Kualitatif, dan R \& D. Bandung: Alfabeta.

Umar, W. (2012). Membangun Kemampuan Komunikasi Matematis dalam Pembelajaran Matematika. Infinity Journal, 1(1), 1-9. 